\title{
PENGARUH PDRB (PRODUK DOMESTIK REGIONAL BRUTO) PERKAPITA DAN INFLASI TERHADAP PENJUALAN OTOMOTIF DI INDONESIA
}

\author{
Akhmad Syari'udin \\ Dosen FEB UPN "Veteran” Yogyakarta \\ e-mail: sariudin2003@yahoo.com
}

\begin{abstract}
ABSTRAK
Perkembangan dunia otmotif Indonesia memiliki perkembangan yang cukup pesat sehingga banyak investor yang melakulan investasi di bidang otomotifnya di Indonesia.Perkembangan pasar otomotif di Indonesia bukan hanya dipengaruhi oleh faktor internal, melainkan dipengaruhi juga oleh faktor eksternal, baik varianel makro maupun variabel mikro. Salah satu variabel makro yang mempengaruhi perkembangan otomotif di Indonesia adalah PDRB Perkapita dan tingkat inflasi dari setiap wilayah pasar otomotif. Penelitian ini bertujuan untuk menganalisis pengaruh PDRB Perkapita dan tingkat inflasi terhadap penjualan otomotif mendasarkan pada 33 wilayah Propinsi di Indonesia. Metodologi yang digunakan adalah regesi terhadap data panel dengan cross section 33 propinsi dan data time series pada Tahun 2016.

Hasi penelitian menunjukkan bahwa: PDRB perkapita secara statistik dan parsial signifikan mempengaruhi penjualan otomotif di 33 wilayah propinsi Indonesia sedangkan variable tingkat inflasi tidak signifikan pada derajat kepercayaan 95\%.Secara simultan kedua variabel PDRB perkapita dan tingkat inflasi mempengaruhi penjualan otomotif di 33 wilayah Indonesia secara signifikan.Dengan demikian maka industri otomotif perlu memperhatikan kedua variabel tersebut dalam mengembangkan penjualan produksinya dan mengembangkan pasar di 33 Propinsi wilayah Indonesia. Selain itu dalam melakukan pengembangan infrasturktur jalan, Pemerintah Indonesia perlu memperhatikan pertumbuhan penjualan otomotif di setiap Propinsi yang ada di wilayah Indonesia.
\end{abstract}

Kata Kunci: PDRB Perkapita, Tingkat Inflasi, Data Panel, Penjualan Otomotif

\section{ABSTRACT}

The development of autmotive Indonesia has a fairly rapid development so that many investors who do investment in the field of automotive in Indonesia. The development of automotive market in Indonesia is not only influenced by internal factors, but also influenced by external factors, both macro variable and micro variable. One of the macro variables affecting automotive development in Indonesia is the per capita GDP and the inflation rate of each automotive market region. This study aims to analyze the influence of per capita GDP and inflation rate on automotive sales based on 33 provinces in Indonesia. The methodology used is the regression of panel data with 33 provinces cross section and time series data in 2016.

The results showed that: per capita GRDP per statistically and partially significant influence of automotive sales in 33 provinces of Indonesia while variable inflation rate is not significant at confidence level95\%. Whereas at 95\% level of confidence, both variables significantly affect automotive sales in Indonesia. In other word, is simultaneously, both the per capita GDP and inflation rate variables significantly influence automotive sales in 33 provincesof Indonesia. Thus, the automotive industry needs to pay attention to these two variables in developing its production sales and developing the market in 33 provinces of Indonesia. The Government of Indonesia, in doing the development of infrastructure should consider the growth of automotive sales in every province in Indonesia.

Keywords: PDRB Percapita, Inflation Rate, Panel Data, Automotive Sales 


\section{PENDAHULUAN}

Perkembangsan dnia otmotif Indonesia memiliki perkembangan yang cukup pesat. Pasar otomotif Indonesia aat ini sudah muai mengejar pasar otomotif Thailand terutama dalam produksi serta ekspor kendaraan roda empat dan memperkuat daya saing industri otomotif nasional.Market otomotif di Indonesia terus tumbuh secara signifikan beberapa tahun terakhir initentunya didukung oleh kondisi ekonomi Indonesia yang cenderung stabil. Stabilitas ekonomi secara teori akan membawa dampak yang positif terhadap bisnis serta investasi di Indonesia, termasuk industri otomotif. Berdasarkan data Gabungan Industri Kendaraan Bermotor Indonesia (Gaikindo), menjelaskan bahwa penjualan otomotif di Indonesia hanya berbeda sekitar 100 ribu unit atau 7,5\% dari Thailand dan pertumbuhan penjualan domestik Indonesia dinyatakan dapat mencapai 23,6\% per tahun.Penelitian Vijay Rao (2016), Automotive and Transportation Practice Frost \& Sullivan, menunjukkan bahwa Indonesia merupakan salah satu perkembangan otomotif terbesar di ASEAN setelah Thailand. Frost \& Sullivan memprediksi bahwa Indonesia akan menjadi pasar otomotif terbesar di ASEAN pada 2019 dengan total kendaraan mencapai 2,3 juta. Indonesia memiliki keunggulan dari Tailand pada jenis kendaraan seperti MPV, truck, pick-up. Namun masih lemah untuk jenis kendaraan sedan yang saat ini masih dikuasai Thailand, sehingga diperlukan analisa yang lebih mendalam dalam hal pangsa pasar disetiap wilayah Indonesia, agar pasar dalam negeri tidak diisi oleh produk-produk industri otomotif dari luar.

Banyaknya investor di bidang otomotifnya di Indonesia karena Indonesia memiliki potensi yang besar, misalnya produsen mobil asal Tiongkok yaitu Build Your Dream Company Ltd (BYD) berdasarkan data dari Gaikindo (20017) menyiapkan investasi awal sebesar 200 juta US Dolar atau setara dengan 1,8 trilliun Rupiah.Dengan pertumbuhan otomotif mobil yang cukup pesat di Indonesia, Jumlah investasi tersebut tentunya masih berpotensi untuk terus meningkat dengan banyaknya inovasi model atau produk baru otomotif di Indonesia, salah satunya adalah LCGC atau yang biasa kita kenal sebagai mobil murah ramah lingkungan. Kebijakan pemerintah yang mewajibkan komponen LCGC menggunakan komponen dalam negeri sebanyak 40\% untuk tahun pertama dan $80 \%$ sampai dengan tahun kelima, akan mendorong industri pengolahan dalam negeri setidaknya $10 \%$.

Produk otomotif seperti Honda, Isuzu, KIA, Mazda, Daihatsu, General Motor, VolksWagen dan lainnya berdasarkan data Gaikindo terus berupaya untuk menambah kapasitas produksinya karena besarnya potensi pasar mobil di Indonesia. Bahkan pendatang baru dari India yaitu TATA Motor akan menjadikan Indonesia sebagai basis produksinya. Toyota bahkan telah menyiapkan investasi sebesar 41,3 milyar yen untuk menambah kapasitas produksi di pabrik Karawang II dari 70.000 unit menjadi 120.000 unit. Mitsubishi juga menyiapkan investasi sebesar Rp 250 milyar Rupiah untuk membangun pabrik baru di Pulogadung, Nissan menyiapkan investasi sebesar 400 juta USD untuk menambah kapasitasnya dari 100.000 unit menjadi 250.000 unit dan masih banyak pesaing lainnya berupaya untuk meningkatkan investasi industri otomotif di Indonesia.Dalam tujuh tahun terakhir, antara 2006-2013, pertumbuhan penjualan mobil di Indonesia mencapai 23,4 persen. Hingga pada Tahun 2012,mencapai1,1 juta unit. Angka itu kemudian meningkat lagi pada tahun 2013 karena ada 1.229.901 unit mobil yang terjual. Pada 2014, pasar otomotif hanya mencapai 1.208.019 unit turun dari 1.229.902 unit pada 2013. Oleh karena pada Tahun 2013 Pasar otomotif Indonesia merupakan volume pasar otomotif terbesar di Indonesia sepanjang sejarah. Harapan pasar otomotif membaik pada tahun 2015 tidak terjadi, tetapi semakin menurn pada sekitar 1.013.291 unit, atau turun 16 persen dibandingkan tahun sebelumnya.Pada Tahun 2017 volume pasar otomotif Indonesia sekitar 1.060.000 unit dan angka produksi mencapai 1.150 .000 unit. Dengan demikian pada Tahun 2017 volume pasar otomotif Indonesia mengalami kenaikan sekitar 4,6 persen dari volume pasar otomotif pada Tahun 2016.Hal ini merupakan awal pertumbuhan pasar otomotif mengalami perlambatan dibanding dengan Tahun 2013 dan 2014. Sedangkan kalau dilihat dari rasio kepemilikan kendaraan roda empat, dapat diperoleh bahwarasio kepemilikan kendaraan roda empat di Malaysia, pada Tahun 2017 sebesar 334 mobil per 1000 orang, di Thailand memiliki rasio 165 mobil per 1000 orang. Sedangkan rasio di Indonesia diperkirakan sebesar 77 mobil per 1000 orang.

Perkembangan pasar otomotif di Indonesia tentunya bukan hanya dipengaruhi oleh faktor internal saja, melainkan banyak sekali faktor eksternal. Salah satu variabel yang mempengaruhi 
adalah pertumbuhan PDRB perkapita dan tingkat inflasi di setiap wilayah di Indonesia. Setelah pemerintahan memberlakukan otonomi daerah, maka tidak jarang suatu daerah memiliki tingkat pertumbuhan di atas tingkat pertumbuhan nasional yang menyebabkan mayoritas para pelaku bisnis kebingungan dalam menerapkan strategi yang efektif dan merata di setiap wilayah yang ada di Indonesia. Untuk itu para pelaku bisnis, khusunya pelaku bisnis di industri otomotif harus selalu mengantisipasi terhadap perkembangan ekonom di setiap wilayah bisnisnya.

Berdasarkan hal-hal tersebut, maka penelitianini mempnyai rumusan sebagai berikut:

a. Bagaimanakah pengaruh PDRB (Produk Domestik Regional Bruto) perkapita secara parsial terhadap penjualan otomotif di 33 propinsi yang ada di Indonesia?

b. Bagaimanakah pengaruh Tingkat Inflasi secara parsial terhadap penjualan otomotif di 33 propinsi yang ada di Indonesia?

c. Bagaimanakah pengaruh PDRB (Produk Domestik Regional Bruto) perkapita dan Tingkat Inflasi secara simultan terhadap penjualan otomotif di 33 propinsi yang ada di Indonesia

\section{TINJAUAN PUSTAKA}

\section{Pengertian Pertumbuhan Ekonomi}

Simon Kuznet (1971) mendefinisikan pertumbuhan ekonomi sebagai kemampuan suatu negara untuk menyediakan barang-barang ekonomi yang terus meningkat bagi penduduknya. Pertumbuhan ini didasarkan pada kemajuan teknologi dan kelembagaan serta penyesuain ideologi yang dibutuhkan. Ketiga komponen ini sangat penting artinya $:^{1}$

a. Kenaikan output nasional yang terus menerus merupakan perwujudan pertumbuhan.

b. kemampuan menyediakan berbagai macam barang ekonomi merupakan tanda kematangan ekonomi.

c. kemajuan teknologi merupakan prasyarat pertumbuhan ekonomi yang berkesinambungan.

Pertumbuhan ekonomi secara umum diartikan sebagai proses kenaikan output (PDB) secara terus-menerus dalam jangka panjang. ${ }^{2}$ Dari pernyataan tersebut kita dapat melihat aspek dinamis dari pembangunan ekonomiyang dilkasanakan, yaitu bagaimana perekonomian tersebut dapat berkembang atau berubah dari waktu ke waktu.Pertumbuhan ekonomi berkaitan dengan kenaikan output perkapita, dimana terdapat dua sisi yang patut untuk diperhatkan. Pertama, dari sisi output total yang mampu dihasilkan oleh perekonomian yang bersangkutan. Kedua, sisi jumlah penduduk sebagai pembagi output yang dihasilkan, sehingga menggambarkan tingkat kesejahteraan yang diperoleh oleh setiap waraga negara yang ditujukan oleh tingkat pendapatan per kapitanya. Meskipun ukuran pendapatan per kapita masih mengandung kelemahan yaitu akan sangat tergangtung pada distribusi pendapatan yang diperoleh golongan-golongan yang ada di dalam masyarakat.

Harrod-Domar mengemukakan teori-teorinya sebagai perluasan dari teori Keynes tentang kegiatan ekonomi nasional dan masalah pemakaian tenaga kerja yang dianggap kurang lengkap karena tidak membahas tentang bagaimana mengatasi persoalan-persoalan ekonomi dalam jangka panjang. Tujuan dari analisa yang dibuat Harrod-Domar adalah untuk melengkapi kekurangan yang ada pada teori Keynes. Teori tersebut pada dasarnya menganalisa persoalan tentang bagaimanakah keadaan yang harus tercipta dalam suatu perekonomian serta syarat-syarat apa yang harus ada untuk menjamin supaya dari waktu ke waktu kemampuan untuk memproduksi yang selalu bertambah sebagai akibat dari penanaman modal akan selalu sepenuhnya digunakan.

\section{PDRB (Produk Domestik Regional Bruto) per Kapita}

PDRB merupakan keseluruhan nilai output perekonomian yang ditimbulkan oleh seluruh kegiatan ekonomi di suatu wilayah, dan dalam suatu kurun waktu tertentu. Kegiatan ekonomi yang dimaksud adalah seluruh kegiatan yang berkaitan dengan potensi sektoral di masing - masing wilayah atau propinsi yang diteliti. Umumnya PDRB per kapita dijadikan sebagai salah satu indikator guna melihat keberhasilan pembangunan perekonomian di suatu

\footnotetext{
${ }^{1}$ Irawan dan M Suparmoko, Ekonomi Pembangunan, BPFE, Yogyakarta, 1992, hal 169

${ }^{2}$ Irawan dan M Suparmoko, Ekonomi Pembangunan, BPFE, Jakarta, 1982, hal 1
} 
wilayah, karena PDRB dapat menggambarkan kemampuan wilayah dalam mengelola segala sumber daya yang dimilikinya. PDRB di suatu wilayah biasanya memiliki besaran yang berbeda-beda tergantung kepada potensi masing-masing wilayah dan bagaimana mereka dapat efektif memanfaatkannya.

Teori-teori perubahan struktur ekonomi menjelaskan bahwa fenomena terjadinya perubahan struktur perekonomian di negara sedang berkembang yang kegiatan perekonomiannya didominasi oleh sektor pertanian atau perekonomian pedesaan bergerak menuju kepada kegiatan perekonomian yang berorientasi pada perekonomian perkotaan dalam bentuk industri maupun jasa.Perubahan struktur perekonomian yang semula mengandalkan sektor pertanian kemudian beralih ke sektor industri maupun jasa, akan dapat mempengaruhi tingkat pendapatan masyarakat, atau tingkat pendapatan antar sektor perekonomian.

\section{Pembangunan ekonomi daerah}

Pembangunan ekonomi daerah adalah suatu proses di mana pemerintah daerah dan masyarakatnya mengelola sumber daya-sumber daya yang ada dan membentuk suatu pola kemitraan antara pemerintah daerah dengan sektor swasta untuk menciptakan suatu lapangan kerja baru dan merangsang perkembangan kegiatan ekonomi atau pertumbuhan ekonomi dalam wilayah tersebut (Arsyad 1999:298). Para ahli ekonomi regional mengatakan bahwa faktor yang mempengaruhi pertumbuhan daerah dalam kaitannya dengan pengembangan kawasan industri yaitu lokasi. Hal ini dapat dipahami bahwa dengan menentukan lokasi yang tepat maka biaya transportasi akan dapat diminimumkan baik untuk mengumpulkan faktor produksi (input) maupun untuk memasarkan hasil-hasil produksi (output). Pembangunan ekonomi daerah mempunyai tujuan utama yaitu meningkatkan dan memperluas peluang kerja bagi masyarakat yang ada di daerah. Untuk mencapai tujuan tersebut, pemerintah daerah dan masyarakatnya harus bersama-sama mengambil inisiatif memanfaatkan seluruh potensi yang ada secara optimal dalam membangun daerah untuk kesejahteraan masyarakat.

\section{Manajemen Pemasaran (Marketing Management)}

Pemasaran (Marketing) merupakan aktivitas sosial yang melibatkan hubungan antara produsen dan konsumen. Menurut kotler (2003), pemasaran merupakan proses sosial dan manajerial yang dilakukan oleh individual maupun kelompok dalam rangka memenuhi kebutuhan dan keinginan melalui suatu proses penciptaan dan pertukaran produk dan nilai dengan pihak lain. Jadi, hakekat utama proses pemasaran adalah upaya penciptaan kepuasan konsumen oleh produsen melalui penciptaan dan pertukaran sesuatu. Fungsi pemasaran merupakan salah satu fungsi pokok dalam suatu organisasi.

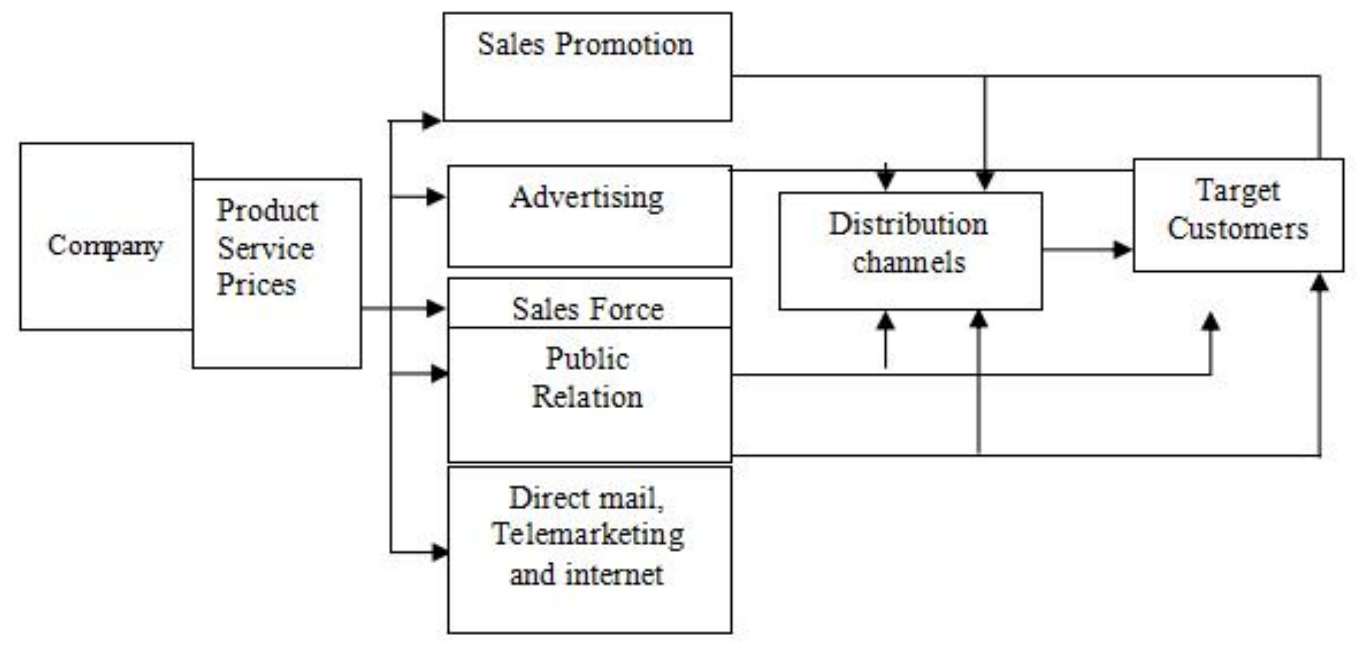

Gambar 1 Proses Manajemen Pemasaran 
Arti penting peran pemasaran bagi organisasi adalah sebagai kunci untuk mencapai tujuan organisasi. Konsep Pemasaran menyatakan bahwa kunci pencapaian tujuan organisasi terletak pada ketepatan penetapatan kebutuhan dan keinginan pasar sasaran dan seberapa efektif dan efisien penyampaian kepuasan tersebut dibandingkan dengan persaingannya (kotler, 2003). Sebagai suatu filosofi, konsep pemsaran disusun dengan memasukan tiga tolok ukur keberhasilan organisasi, yaitu (1) orientasi pada konsumen, (2) volume penjualan, dan (3) koordinasi dan intergrasi seluruh aktivitas pemasaran.konsep pemasaran yang sering digunakan adalah konsep marketing mixyang mempunyaiempat variabel kunci, yaitu Product, Price, place, dan promotion. Penerpan strategi marketing mix tidak terlepas dari sistem lingkungan yang memiliki kompenenkompenen berupa faktor-faktor lingkungan yang berpengaruh terhadap proses implementasi strategi tersebut. Product merupakan segala sesuatu, baik yang tampak (Tangiable) maupun yang tidak tampak (intangiable), yang diciptakan untuk memenuhi kebutuhan dan keinginan konsumen mulai dari awal sampai akhir proses pemasaran. Menurut Kotler (2003) produk bisa berupa barang (goods), jasa (Services), Tempat (Places), orang (Persons), maupun ide (idea). Price merupakan nilai produk yang diekspresikan dalam satuan moneter atau nilai tukar uang. Penetepan harga perlu dilakukan secara tepat untuk mencapai target kepuasan konsumen dan memberikan kontribusi keuntungan bagi organissai. Maksimalisasi keuntungan lebih merupakan kebijakan jangka panjang, sedangkan target return biasanya ditetapkan untuk jangka pendek. Placemerupakan variabel pemasaran yang menentukan saluran pemasaran produk kepada konsumen.Ada dua isu penting untuk dipertimbangkan bagi kebijakan dalam pemasaran yang terkait dengan daerah adalah:

a. Peranan baru dalam konteks persaingan pemasaran daerah yang senantiasa mengalami perubahan,

b. Dampak terjadinya perubahan kondisi dan faktor-faktor yang berpengaruh terhadap pengambilan keputusan.

\section{METODOLOGI PENELITIAN}

Metode penelitian yang digunakan dalam penelitian ini adalah studi kasus di wilayah propinsi di Indonesia dengan menggunakan data sekunder. Data dapat diperoleh dari BPS (Badan Pusat Statistik) dan Gaikindo (Gabungan Industri Kendaraan Bermotor Indonesia) dan metode analisis dalam penelitian ini menggunakan analisis kuantitatif serta regresi dengan menggunakan data panel, yaitu penggabugan data runtut waktu (time series) dengan data kuartalan pada tahun 2016 dan data antar ruang (cross section) di 33 propinsi di Indonesia.

Metode dalam penelitian ini adalah OLS (Ordinary Least Squares). Model OLS dengan model sebagai berikut:

$$
\mathbf{y}_{i t}=\alpha+\beta_{1} \mathbf{x}_{1 t t}+\beta_{2} \mathbf{x}_{2 i t}+\varepsilon_{i t}
$$

dimana :

$\mathrm{y}_{\text {it }} \quad=$ Variabel Pasar Otomotif unit cross section ke-i waktu ke- $\mathrm{t}$

$\mathrm{X}_{1}$ it $=$ Variabel PDRB Perkapita Propinsi ke-i pada waktu ke-t

$\mathrm{X}_{2}$ it $=$ Variabel Inflasi Propinsi ke-i pada waktu ke- $\mathrm{t}$

$\beta_{1} \quad=$ Koefisien variabel PDRB PerkapitaPropinsi $\mathrm{k}$

$\beta_{2} \quad=$ Koefisien variabel InflasiPropinsi $\mathrm{k}$

$\alpha=$ Konstanta

$\varepsilon_{\text {it }}=$ Error term

Analisis dalam penelitian ini menggunakan $\alpha=5 \%$ dan menggunakan dua pendekatan mendasar yaitu:

1. Pendekatan fixed effect yang menetapkan bahwa $\alpha$ i adalah sebagai kelompok yang spesifik atau berbeda dalam constant term dalam model regresinya.

2. Pendekatan random effect yang meletakkan ai adalah gangguan spesifik kelompok, sama dengan eit kecuali untuk masing-masing kelompok. Tetapi untuk gambaran tunggal yang memasukkan regresi sama untuk tiap-tiap periode.

Untuk menentukan pendekatan yang tepat antara fixed effect dengan random effect dilakukan pengujian dengan menggunakan Hausman Test,. Hipotesis Hausman test yang akan diuji adalah: 
$\mathrm{H} 0=\alpha$ i tidak berkorelasi dengan variabel bebas

$\mathrm{Ha}=\alpha$ i berkorelasi dengan variabel bebas.

Jika H0 ditolak maka metode yang tepat adalah random effect.

$\mathrm{W}=(\mathrm{BFE}-\mathrm{BRE})(\mathrm{COVFE}-\mathrm{COVRE})-1(\mathrm{BFE}-\mathrm{BRE})$

Di mana:

$\mathrm{W} \sim \chi 2 \mathrm{df}=\Sigma$ koefisien

Pengujian statistik dan kesesuaian dengan assumsi klasik dilakukan untuk mendapatkan model estimasi yang berifat stokastik dan tidak berifat spuriousregression. Uji statistik meliuti: Uji t (Student's Test) dan Uji R ${ }^{2}$. Sedangkan Pengujian terhadap assumsi klasik meiputi: Uji Normalitas dan Multikolinearitas.

\section{HASIL DAN PEMBAHASAN}

Rata-rata pertumbuhan penjualan otomotif di 33 Propinsi wilayah Indonesia dapat ditemukan bahwa: rata-rata pertumbuhan selama tahun kajian, yaitu tahun 2012-2016 mempunyai rata-rata sebesar 25 persen pertahun dengan pertubuhan tertinggi di wilayah Papua barat yaitu sebesar 47 persen dan pertumbuhan terkecil di wilayah sumatra utara sebesar 7 persen. Berdasarkan data Gaikindo otomotif jenis minbus menjadi kendaraan yang juga cocok untuk wilayah Papua dengan kondisi alam pegunungan dan infrastruktur jalan yang kadang kasar. Sebagian besar konsumen berasal dari dinas instansi pemerintah dan swasta, serta bisnis seperti penyewaan mobil dan taksi bandar udara (bandara). Oleh karena itu selain oleh karena kondisi alam serta jalan kecil dan kasar, pertimbangan harga menjadi pertimbangan konsumen di Papua.

Analisis regresi adalah studi tentang keterkaitan suatu variabel dependen (tidak bebas) dengan satu atau lebih variabel independen (bebas atau penjelas) untuk mengestimasi nilai ratarata populasi variabel dependen berdasarkan nilai tetap variabel independen (Gujarati, 2009 : 16). Estimasi yang akan dilakukan pada penelitian ini adalah menggunakan model ekonometri, statis, dengan menggunakan OLS (Ordinary Least Squares). Model OLS digunakan untuk mendapatkan gambaran hubungan teoritis antara penjualan otomotif sebagai variabel dependen dengan PDRB Perkapita dan Inflasi sebagai variabel independen.

Pengujian dilakukan dengan uji tahap pertama (kriteria statistik) yang meliputi signifikansi parameter-parameter secara individual, uji signifikansi parameter secara bersamasama dan uji kesesuaian (goodness of fit) dan uji tahap kedua (kriteria ekonometri) yaitu tidak adanya penyimpangan-penyimpangan asumsi linear klasik,terutama linearitas, normalitas, non autokorelasi, non multikolinearitas, dan homoskedastisitas. Semua pengujian ini dengan memanfaatkan program eviews7. Kriteria statistik hanya akan valid apabila asumsi-asumsi linier klasik terpenuhi.Model Pengaruh PDRB per kapita dan Inflasi Terhadap penjualan Otomotif dari hasil Hausman test diperoleh bahwa model yang direkomendasikan adalah model fixed effect (Fixed Effect Model/FEM). Berdasarkan hasil uji Hausman, maka model fixed effect (Fixed Effect Model)mengassumsikan bahwa koefisien regresi (slope) tetap antar propinsi dan antar waktu dan intersepnya berbeda antar propinsi. Adapun persamaan regresi fixed effect model adalah sebagai berikut :

$$
Y=-55.446,90+8,24 X 1-3.590,49 X 2+\mu
$$

Konstanta dari persamaan regresi mempunyai nilai signifikasi dari besarnya probabilitas sebesar 0,000 yang lebih kecil dari nilai $\alpha=5$ persen atau mempunyai nilai t statistik sebesar 6,00 yang lebih besar dari t tabel $(n=163 ; \alpha=5 \%)$ sebesar 1,65 . Sehingga konstanta berpengaruh secara signifikan terhadap penjualan otomotif di 33 Propinsi di Indonesia dengan nilai koefisien konstanta $\beta o=-55446.91$. Hal ini mempunyai makna bahwa: jika pertumbuhan PDRB per kapita dan Inflasi sama dengan nol (0) atau caterisparibusmaka penjualan otomotif akan turun sebesar 55.446 unit. Koefisien PDRB Perkapita, $\beta 1=8,24$. Artinya bahwa jika PDRB perkapita naik satu satuan maka penjualan otomotif naik sebesar 8 satuan. Karena perhitngan data PDRB Per-Kapita dalam satuan ribu, maka sebagai contoh jika PDRB Perkapita naik sebesar Rp. 1.000.000,- maka penjualan otomotif akan naik sebesar 8000 unit. Variabel inflasi tidak memepngaruhi secara signifikan terhadap penjualan otomotif, oleh karena itu, berapapun perubahan inflasi tidak akan mempengaruhi penjualan otomotif di 33 Propinsi di Indonesai. Hal ini 
dikarenakan konsumen dalam berprilaku membeli kendaraan roda empat pada umumnya didasarkan pada aspek kebutuhan, aspek gaya hidup dan aspek investasi.

Nilai F hitung didasarkan pada olahan data diperoleh sebesar 68.69509 yang lebih besar dari nilai $\mathrm{F}$ tabel $((\mathrm{n}=163 \alpha=5 \%)$ yaitu sebesar 3,05. Hal ini menunjukkan bahwa variabel PDRB perkapita dan inflasi secara bersama-sama (simultan) mempengaruhi penjualan otomotif secara signifikan. Hasil nilai koefisien determinasi Adj. $\mathrm{R}^{2}$ sebesar 0.93424. Hal ini menunjukkan bahwa variabel penjualan otomotif dipengaruhi variabel yang ada dalam model sebesar 93 persen dan sisanya sebesar 7 persen dipengaruhi variabel lain diluar model.

Uji tahap kedua atau yang dikenal dengan uji ekonometrika ini merupakan pengujian terhadap pelanggaran asumsi klasik. Dalam penelitian ini, peneliti mencoba mengganalisis beberapa pengujian assumsi klasik saja yang meliputi :

\section{Uji Normalitas}

Dalam penelitian ini digunakan JarqueBera (J-B) test didapat dari histogram normality (lampiran 2).Hasil pengolahan data (gambar 3) menujukkan bahwa nilai JarqueBera (J-B) nya sebesar 0,698. Nilai ini lebih kecil dari Chi Square tabel $(\mathrm{n}=163$ dan $\alpha=5 \%$ ) sebesar: 7,38. Hal ini menunjukkan bahwa hipotesisi nol tersebut dapat diterima, atau dengan kata lain residualnya berdistribusi normal (memenuhi assumsi klasik).

\section{Uji Non-Multikolinearitas}

Untuk menguji masalah multikolinearitas dapat melihat matriks korelasi dari variabel bebas, jika terjadi koefisien korelasi lebih dari 0,80 maka terdapat multikolinearitas (Gujarati, 2009).Hasil olah data (lampiran 3) menunjukkan nilai matrik korelasi sebesar 0,014 yang lebih kecil dari 0,8 . Sehingga hal ini menunjukkan bahwa tidak terjadi multikolineritas antara variabel PDR Perkapita di 33 wilayah Indonesia dengan tingkat inflasi selama kajian dilakukan (tahun 2014-2016).

Berdasarkan hasil analisa kuantitatif tersebut, maka dapat dijelaskan bahwa penjualan otomotif di Indonesia tidak bisa lepas dari Produk Domestik Regional Bruto (PDRB) Perkapita yang telah dicapai Indonesia. Tentunya hal in seharusnya diimbangi dengan pertumbuhan ekonomi. Beberapa faktor yang akan menentukan kinerja penjualan otomotif di Indonesia antara lain adalah daya beli masyarakat dan inflasi selain oleh karena jumlah penduduk Indonesia yang relatif banyak. Oleh karena itu, perlu ada upaya peningkatan kemampuan daya beli masyarakat dan tentunya upaya menekan dan kepastian laju inflasi. Sehingga pasar otomotif Indonesia dapat diprediksi membutuhkan waktu relatif tidak lama untuk dapat melebihi Thailand yang diproyeksikan tetap merajai pasar otomotif ASEAN. Indonesia masih membutuhkan tambahan investasi yang relatif tinggi untuk menambah kapasitas produksi mobilnya. Walaupun pernah pada Tahun 2014 penjualan mobil di pasar domestik Indonesia tercatat sebagai yang paling tinggi di Asia Tenggara dengan total penjualan 107.456 unit. Sementara itu, Thailand hanya menjual 68.508 unit mobil di pasar domestiknya. Pencapaian tersebut diharapkan dapat terus meningkat pada masa-masa yang akan datang. Dengan asumsi penjualan berkisar 100.000 unit per bulan, maka target 1,2 juta unit dari Gaikindo bisa tercapai bahkan dapat melebihi target yang telah ditentukan.

\section{PENUTUP}

Dari hasil pebelusuran data maka dapat disimpulkan dan disarankan sebagai berikut :

\section{Kesimpulan}

a. Variabel PDRB Perkapita berpengaruh signifikan terhadap Penjualan Otomotif di 33 Propinsi di Indonesia. Sehingga dapat disimpulkan bahwa $\mathrm{H}_{1}$ tidak ditolak.

b. Variable Inflasi tidak berpengaruh secara signifikan terhadap Penjualan Otomotif di 33 Propinsi di Indonesia. Sehingga dapat disimpulkan bahwa $\mathrm{H}_{2}$ ditolak.

c. Pengaruh variabel PDRB Perkapita dan Inflasi secara simultan berpengaruh signifikan terhadap Penjualan Otomotif di 33 Propinsi di Indonesia. Sehingga dapat disimpulkan bahwa $\mathrm{H}_{3}$ diterima. 


\section{Saran}

Berkaitan dengan pertumbuhan penjualan otomotif dan Produk Domestik Regional Bruto (PDRB) Perkapita serta inflasi, maka dapat disarankan Bagi Industri atau Pelaku Usaha sebagai berikut :

a. Industri otomotif perlu memperhatikan tingkat PDRB Perkapita dalam mengembangkan penjualan produksinya dan mengembangkan pasar di 33 Propinsi wilayah Indonesia.

b. Inflasi wlaupun tidak mempengaruhi secara parsial terhadap penjualan otomotif, namun secara simultan bersama PDRB Perkapita, inflasi mempengaruhi pennjualan otomotif secara signifikan. Oleh karen itu lau inflasi menjadi salah satu pertimbangan dalam menjalankan strategi penjualan di 33 Propinsi wilayah Indonesia.

Sedangkan saran penulis bagi Penentu Kebijakan adalah sebagai berikut :

a. Perlu mengarahkan pemanfaatan CSR untuk pengembangan infrastruktur jalan di 33 Propinsi wilayah Indonesia. Hal ini oleh karena peningkatan PDRB Perkapita menjadi salah satu pilar yangdiupayakan oleh pemerintah.

b. Dalam melakukan pengembangan infrasturktur jalan, pemerintah perlu untuk memperhatikan pertumbuhan penjualan otomotif di 33 Propinsi wilayah Indonesia.

c. Perlu ada penelitian lanjutan terkait dengan kebutuhan riil atas otomotif dan ketersediaan infrastruktur di 33 Propinsi wilayah Indonesia.

\section{DAFTAR PUSTAKA}

Arsyad, Lincoln. 1999. Ekonomi Pembangunan, Edisi Keempat.Yogyakarta : BP STIE YKPN

Boediono, "Seri Sinopsis Pengantar Ilmu Ekonomi No.2 Ekonomi Makro, BPFE, Yogyakarta, 1986

Kotler, Philip.2003. Manajemen Pemasaran. edisi kesebelas, Jakarta: Indeks kelompok

Gramedia. Gujarati, Damodar N, 2009, Basic Econometrics, $5^{\text {rd }}$ Ed, McGraw-Hill International, Newyork.

Salvatore Dominick, “Ekonomi Internasional”, Erlangga, Jakarta, 1997

Thomas, R.L., 1997, Modern Econometrics An Introduction, Addision Wesley Longman, England

Badan Pusat Statistik, 2015, Data Produk Domestik Regional Bruto Per kapita Atas Dasar Harga Konstan 2000, Jakarta.

Badan Pusat Statistik, 2016, Data Produk Domestik Regional Bruto Per kapita Atas Dasar Harga Konstan 2000, Jakarta.

APBN 2008. "Nota Keuangan dan APBN 2008” www.google.com diakses 23 Agustus 2010. 